\section{A FIRST REPORT OF SYMBIOTIC POLYCHAETE SCALE WORM GASTROLEPIDIA CLAVIGERA SCHMARDA, 1861 (PHYLLODOCIDA: POLYNOIDAE) FROM LAKSHADWEEP ARCHIPELAGO, INDIA}

\section{Thangapandi Marudhupandi ${ }^{1}$, Thipramalai Thangappan Ajith Kumar ${ }^{2}$, Sanjeevi Prakash ${ }^{3}$, Mohan Gopi ${ }^{4}$ \& Thangavel Balasubramanian ${ }^{5}$}

$1,2,3,4,5$ Centre of Advanced Study in Marine Biology, Faculty of Marine Sciences, Annamalai University, Porto Novo, Tamil Nadu 608502, India

Present address: ${ }^{2}$ National Bureau of Fish Genetic Resources (ICAR), Canal Ring Road, Dilkusha Post, Lucknow, Uttar Pradesh 226002, India ${ }^{3}$ Centre for Climate Change Studies, Sathyabama University, Jeppiaar Nagar, Rajiv Gandhi Salai, Chennai, Tamil Nadu 600119, India ${ }^{1}$ tmarudhu@gmail.com, ${ }^{2}$ ttajith87@gmail.com,

${ }^{3}$ prakash.s1311@gmail.com (corresponding author),

${ }^{4}$ gpsakthi@gmail.com, ${ }^{5}$ stbcas@nic.in

The fact that symbiotic polychaete species are assigned to have commensal association with other marine invertebrates is a common phenomenon. The effects of a symbiont on their hosts determine the type of their interactions and many of these associations are poorly understood since their study requires much time and effort (Britaev \& Lyskin 2002). Martin \& Britaev (1998) describe 375 species of symbiotic polychaetes with 294 considered as commensal and 81 said to be parasitic. More than 50 species of symbiotic polychaetes belong to the family Polynoidae, which are commonly occurring medium-sized scale worms (Fauchald 1977).

In the present study a survey for

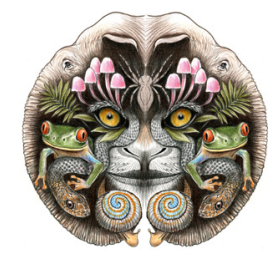

ISSN

Online 0974-7907 Print 0974-7893

\section{OPEN ACCESS} commensal scale worms was confined to the intertidal area (eastern side) of Agatti Island, Lakshadweep during the months of September and October 2011. In total, 52 belt transects $(50 \times 10 \mathrm{~m})$ were positioned between high and mid tidal regions with a distance of $100 \mathrm{~m}$ among each of the transects. The individuals of symbiotic polychaete Gastrolepidia clavigera Schmarda (Image $1 a, b)$ were counted by observing from the body surface of the hosts dorsally, central and near the oral cavity. The holothurian host was less abundant in the low tidal region due to rocky areas and hence, the survey was restricted to the middle and southeastern side of the Agatti Island where sandy substrates were more common. Underwater documentations were done by an Olympus camera ( $\mu$ Tough series) over the depth ranges from $0-1.5 \mathrm{~m}$. Worms were often found in pairs and associated with a variety of holothurians belonging to the families Holothuridae and Stichopodidae. The worms were clinging to the anterior or posterior end of the host body, but when disturbed they tended
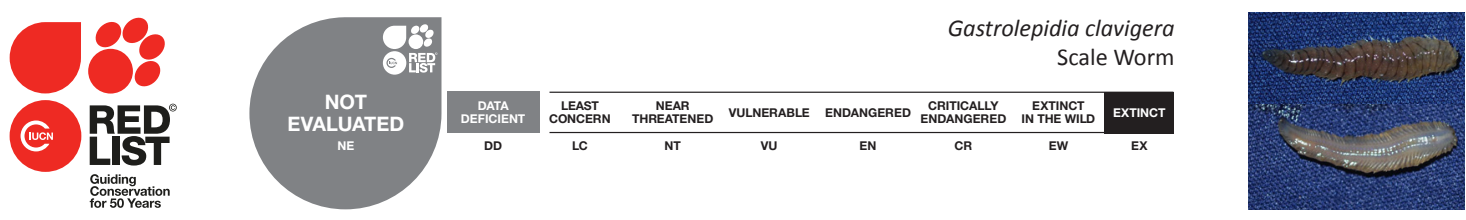

DOI: http://dx.doi.org/10.11609/JoTT.03092.6385-8 | ZooBank: urn:Isid:zoobank.org:pub:3B06F767-2729-4395-A520-EBC7D162E37A

Editor: Robin Wilson, Museum Victoria, Melbourne, Australia

Date of publication: 26 September 2014 (online \& print)

Manuscript details: Ms \# 03092 | Received 10 September 2012 | Final received 23 May 2014 | Finally accepted 10 August 2014

Citation: Marudhupandi, T., T.T.A. Kumar, S. Prakash, M. Gopi \& T. Balasubramanian (2014). A first report of symbiotic polychaete Scale Worm Gastrolepidia clavigera Schmarda, 1861 (Phyllodocida: Polynoidae) from Lakshadweep Archipelago, India. Journal of Threatened Taxa 6(10): 6385-6388; http://dx.doi.org/10.11609/ JoTT.03092.6385-8

Copyright: () Marudhupandi et al. 2014. Creative Commons Attribution 4.0 International License. JoTT allows unrestricted use of this article in any medium, reproduction and distribution by providing adequate credit to the authors and the source of publication.

Funding: Ministry of Earth Sciences, Government of India under the project entitled "Development of technologies for hatchery production of ornamental fishes at Lakshadweep : Sea ranching and technology transfer to coastal and island communities"

Competing Interest: The authors declare no competing interests.

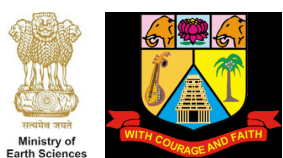

Acknowledgements: The authors are grateful to their Dean, Faculty of Marine Sciences and the authorities of Annamalai University for the facilities provided. This work was supported by the Centre for Marine Living Resources and Ecology (CMLRE), Ministry of Earth Sciences, Government of India. 


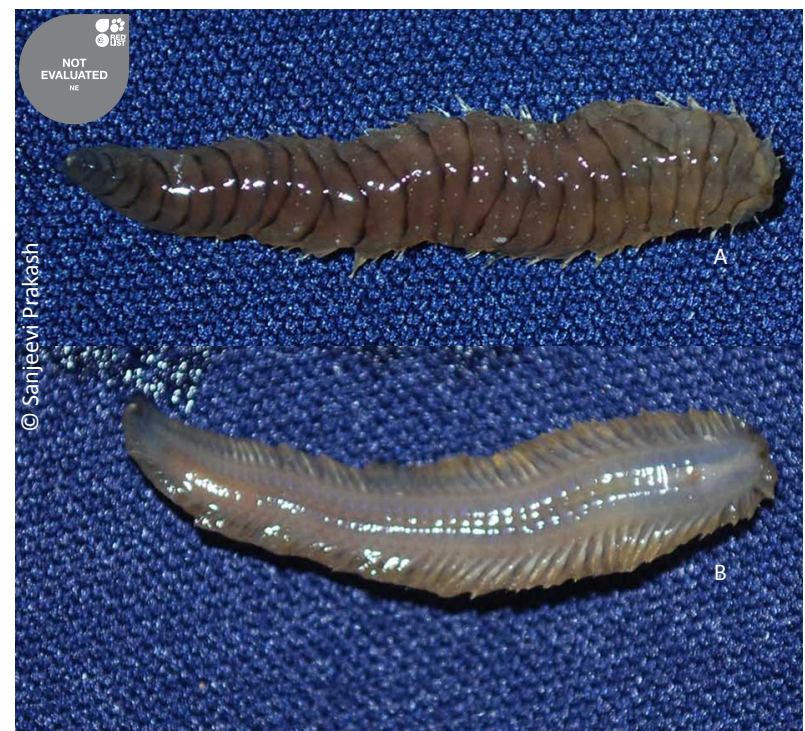

Image 1. Symbiotic polychaete Gastrolepidia clavigera Schmarda, 1861 (TL 21mm) $\left(10^{\circ} 50^{\prime} 39.80^{\prime \prime} \mathrm{N} \& 7^{\circ}{ }^{\circ} 11^{\prime} 16.85^{\prime \prime} \mathrm{E}\right)$ (MBRC/ZSI M -64), 22.x.2011, intertidal, Agatti, Lakshadweep, India.

A - same-dorsal view; B - same-ventral view.

to hide inside the oral cavity of the host. The size of worms was measured in millimeters (total length in $\mathrm{mm}$ ) and the host was measured in centimeter (total length in $\mathrm{cm}$ ). Host holothurians were identified using field guides (Allen \& Steene 2000) and worm specimens were identified using Hanley (1989), Britayev et al. (1999) and Barnich et al. (2004). Description and coloration of the symbiotic worm $G$. clavigera was based on the recently collected specimens and further used for taxonomic identifications. The samples were preserved in 5-10 $\%$ sea water formalin and deposited in the Marine Biological Regional Centre (MBRC), Zoological Survey of India (ZSI), Chennai, Tamil Nadu.

Order Phyllodocida Dales, 1962

Suborder Aphroditiformia Levinsen, 1883

Family Polynoidae Malmgren, 1867

Genus Gastrolepidia Schmarda, 1861

Gastrolepidia clavigera Schmarda, 1861 (Image 1 A,B; Fig.1 A-E)

Material examined: MBRC/ZSI $\mathrm{M}_{1}-64,11$ individuals, 22.x.2011, TL 11-24 mm, intertidal area (eastern side), Agatti Island, Lakshadweep $\left(10^{\circ} 50^{\prime} 39.80^{\prime \prime} \mathrm{N}\right.$ \& $\left.72^{0} 11^{\prime} 16.85^{\prime \prime} \mathrm{E}\right)$, coll. T. Marudhupandi \& S. Prakash.

Diagnostic characters: Body flattened, tapering anteriorly and posteriorly up to 36 segments, scute-like processes at the base of each parapodium. Elytra large, smooth and soft without papillae, overlapping medially and posteriorly (Fig. 1A). Elytron with pouch on anterior margin. Prostomium bilobed and wider, without

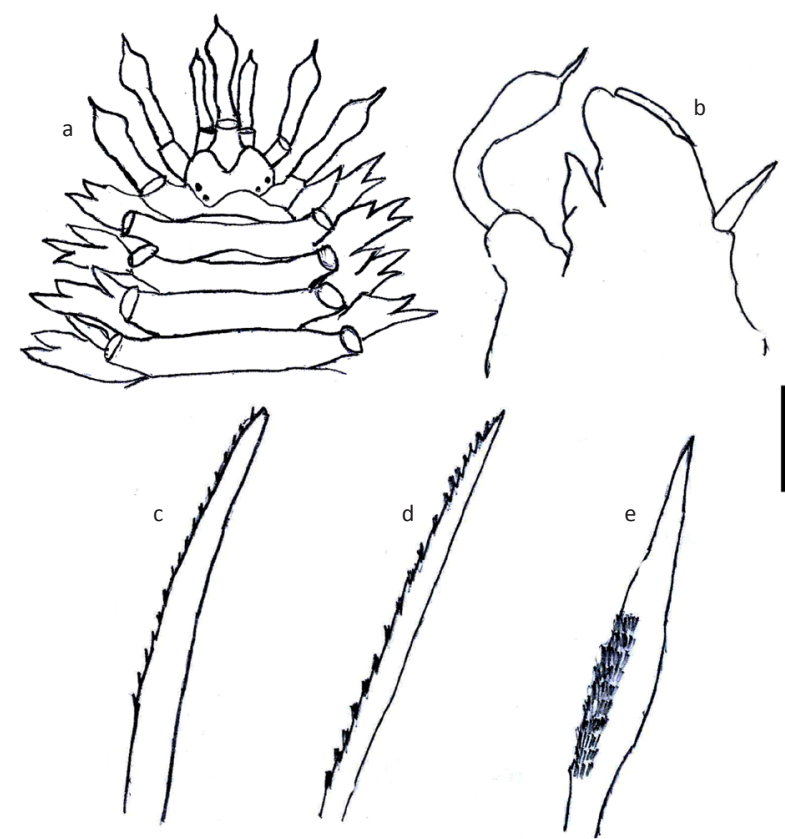

Figure 1. Symbiotic polychaete G. clavigera Schmarda, 1861

A - anterior end (dorsal view); B - cirrigeous parapodium (posterior view); C - notosetae; D - neurosetae (upper); E - same (middle). Scale: $A=1 \mathrm{~mm} ; B=0.5 \mathrm{~mm} ; C-E=0.1 \mathrm{~mm}$.

cephalic peaks, palps short and tapering gradually to a filiform tip. Ceratophores of median antenna large and truncated in anterior notch, style smooth, basally cylindrical and expanding to large bulbous subterminal inflation and lateral antenna distinct, shorter and smaller, terminoventrally on distal ends of prostomium.

Tentacular segments not visible, tentaculophores lateral to prostomium with two pairs of dorsal and ventral tentacular cirri, smooth and similar to median antenna. Parapodia subbiramous (Fig. 1B). Notopodium small and flattened with acicular lobe. Neuropodium deeply cut dorsally and ventrally forming a long and thin presetal lobe and short and blunt postsetal lobe. Dorsal cirri withour elytra expanding into large subterminal inflation and form filiform tip. Ventral cirri shorter and gradually form filiform tip. Ventral lamellae large and conspicuous at the bases of parapodia.

Notosetae (Fig. 1C) long and slightly curved with serrations on the outer margin with notched tips. Neurosetae (Fig. 1D) long and straight with rows of serrations at the outer egdes with notched tips; middle (Fig. 1E) and lower neurosetae short and stout, slightly curved with a few rows of serrations and unindentate tips.

Distribution: Gastrolepidia clavigera has a circumtropical distribution throughout the Indo-Pacific 


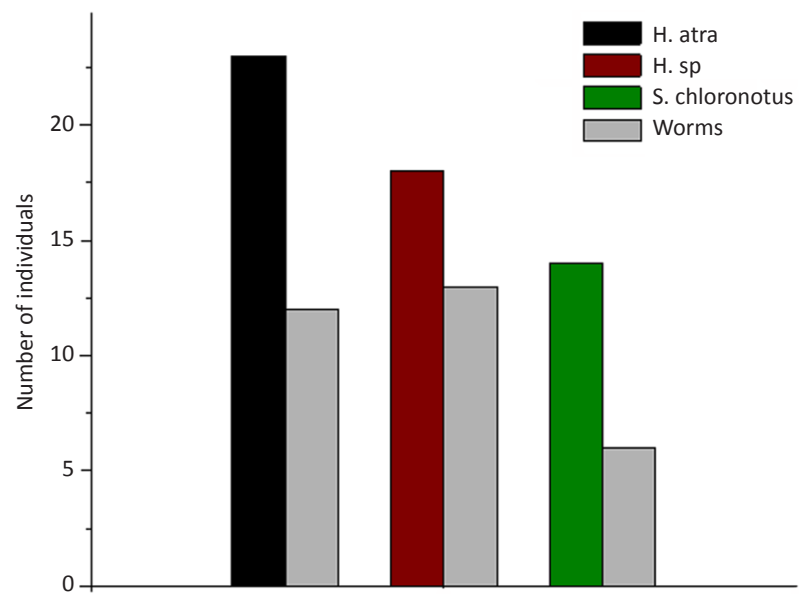

Figure 2. Number of holothurians containing G. clavigera as commensal. Holothuria atra (12 out of 23), Holothuria. sp (13 out of 18) and Stichopus chloronotus (6 out of 14)

(Hanley 1993; Martin \& Britayev 1998), the South China Sea, Xinsha Islands (Wu et al. 1975), southern Vietnam (Britayev \& Zamishlyak 1996) and Hainan Island (Meng et al. 1993; Barnich et al. 2004). In Indian waters it has been recorded from Rameswaram (Fauvel 1941) and Andaman and Nicobar Islands (Tampi \& Rangarajan 1964; Tikader et al. 1986). This species has been reported for the first time from Agatti Island, Lakshadweep.

Remarks: Potts (1910) was the first to recognize the association between $G$. clavigera and the holothurians. Gibbs $(1969,1972)$ provided a list of holothurian hosts and suggested that the ventral lamellae might be an adaptation to life on a holothurian, allowing the worms to cling by suction to their hosts.

Nearly 26 species of holothurians have hitherto been recorded from Lakshadweep waters (James 1989) of which 11 species were recorded during the present survey. The $G$. clavigera was mainly found in abundance when associated with three species of holothurians: Holothuria atra, Holothuria sp. (Holothuridae) and Stichopus chloronotus (Stichopodidae). The maximum length of the host was measured as 42.2, 27.8 and 22.5 $\mathrm{cm}$ respectively. The remaining host species (Bohadschia argus, Actinopyga mauritiana and Holothuria nobilis) were rarely seen during the survey with worm as a commensal. One further holothurian species in this region is Synaptus sp. (Synaptidae), which does not host any symbiotic worm on its body surface (personal observation by TM, SP and MG during the survey).

In total, 55 host individuals were observed for the presence of symbiotic worm and 31 individuals were holding $G$. clavigera in a commensal relationship. Holothuria atra (12 of 23), Holothuria sp. (13 of 18) and

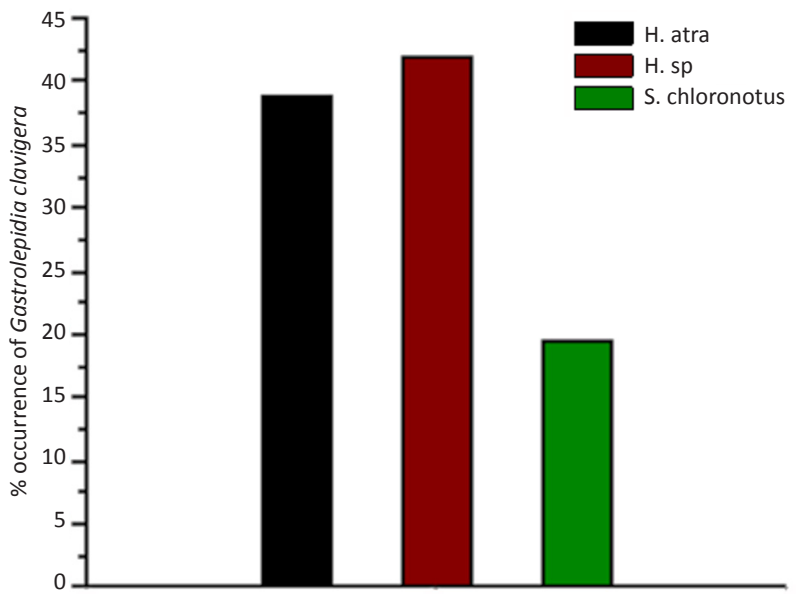

Figure 3. Percentage (\%) occurrence of G. clavigera associated with three species of holothurians

Stichopus chloronotus (6 of 14) (Fig. 2), respectively. Percentage (\%) occurrence of symbiotic worm $G$. clavigera on these three host species were calculated. The maximum occurrence was on Holothuria sp. (41.9\%) followed by $H$. atra (38.7\%), suggesting that the surface area of the host may play a vital role in the distribution of these symbiotic worms on the body surface. Whereas a low \% occurrence on S. chloronotus (19.3\%) is due to the lesser body surface of the host species (Fig. 3), in rare occasions, more than two worms were noticed in Holothuria sp. including juveniles of $8 \mathrm{~mm}$ and $11 \mathrm{~mm}$ in total length.

Both parasitic feeding on the host's tissues and predatory behavior are characteristic of G. clavigera, which makes up a complex system of interactions between the polychaete and their host holothurians (Britaev \& Lyskin 2002). Both field and experimental studies are required to study the interactions between these symbionts and their hosts.

\section{References}

Barnich, R., D. Fiege \& R. Sun (2004). Polychaeta (Annelida) of Hainan Island, South China Sea Part III Aphroditoidea. Species Diversity 9: 285-329

Britayev, T.A. \& E.A. Zamishlyak (1996). Association of commensal scale worm Gastrolepidia clavigera (Polychaeta: Polynoidae) with holothurians near the coast of South Vietnam. Ophelia 45: 175-190; http://dx.doi.org/10.1080/00785326.1996.10432470

Britayev, T.A., G. Doignon \& I. Eeckhaut (1999). Symbiotic polychaetes from Papua New Guinea associated with echinoderms, with descriptions of three new species. Cahiers de Biologie Marine 40: 359-374

Britaev, T.A. \& S.A. Lyskin (2002). Feeding of the Symbiotic Polychaete Gastrolepidia clavigera (Polynoidae) and Its Interactions with Its Hosts. Doklady Biological Sciences 385: 352-356; http://dx.doi. org/10.1023/A:1019964918471 
Fauchald, K. (1977). The Polychaete Worms-Definitions and Keys to the Orders, Families and Genera. Nat Hist Mus Los Angeles County. Science series 28, 198pp

Fauvel, P. (1941). On a small collection of Annelida Polychaeta of the Indian Museum, Calcutta. Records of Indian Museum, Zoological Survey of India, Calcutta 42: 253-268

Gibbs, P.E. (1969). Aspects of Polychaete ecology with particular reference to commensalism. Philosophical Transactions of the Roya Society of London, B Biological Sciences 255: 443-458; http://dx.doi. org/10.1098/rstb.1969.0020

Gibbs, P.E. (1972). Polychaete annelids from the Cook Islands. Journal of Zoology, London 168: 199-220; http://dx.doi. org/10.1111/j.1469-7998.1972.tb01347.x

Hanley, J.R. (1989). Revision of the scale-worm genera Arctonoe Chamberlin and Gastrolepidia Schmarda (Polychaeta, Polynoidae) with the erection of a new subfamily Arctonoinae. The Beagle, Occasional Papers of the Northern Territory Museum of Arts and Sciences 6: 1-34.

Hanley, J.R. (1993). Scaleworms (Polychaeta: Polynoidae) of Rottnest Island, Western Australia, pp. 203-236. In: Wells, F.E., D.I. Walker, H Kirkman \& R. Lethbridge (eds.). Proceedings of the fifth International Marine Biological Workshop. The Marine Flora and Fauna of Rottnest Island, Western Australia. Western Australian Museum, Perth.

James, D.B. (1989). Echinoderms of Lakshadweep and their zoogeography, 93-149. In: Marine Living Resources of the Union Territory of Lakshadweep. CMFRI Bulletin 43.

Martin, D. \& T.A. Britayev (1998). Symbiotic polychaetes: review of known species. Oceanography and Marine Biology Annual Review 36: $217-340$

Meng, F., X. Hong \& B. Wu (1993). Studies on the polychaeta of Hainan Island waters I. Journal of Oceanography of Huanghai and Bogai Seas 11(4): 45-63

Potts, F.A. (1910). Polychaeta of the Indian Ocean - part 2. The Palmyridae, Aphroditidae, Polynoidae, Acoetidae, Sigalionidae. Transactions of the Linnean Society of London, Series 2 Zoology 16(2): 325-353

Tampi, P.R.S. \& K. Rangarajan (1964). Some polychaetous annelids from the Andaman waters. Journal of Marine Biological Association of India 6(1): 98-123

Tikader, B.K., A. Daniel \& N.V. Subbarao (1986). Sea Shore Animals of Andaman and Nicobar Islands. The Director, Zoological Survey of India, Kolkata 188pp.

Wu, B., S. Shen \& M. Chen (1975). Preliminary report on polychaetous worms from the Xinsha Islands, Guand dong Province, China. Studia Marina Sinica 10: 65-104 (in Chinese with English abstract) 